\title{
The Differences of Ability in the Level of Development on Control Objects of Early Childhood Education Students in Pariaman City and Padang Panjang City
}

\author{
Arie Asnaldi, Reki Yelis*, Zulman, Atradinal, Lucy Pratama Putri, Syahrial Bakhtiar \\ Faculty of Sport Science \\ Padang State University \\ Padang, Indonesia \\ *rekiyelis13@gmail.com
}

\begin{abstract}
Based on the observation, the problem in this study is the level of the children's basic motion is still in a low level, especially the ability of the control object. In West Sumatera, especially in some areas that researchers have visited, the difference in the level of basic motion is quite significant. Many factors are predicted to influence the difference in the development level of the basic motion and one of the causes that researchers consider the most dominant is residential areas, especially coastal areas and mountainous areas. This study aims to perceive differences in the level of development of children control object ability. The population in this study was all students in Pariaman city and Padang Panjang city. The random sampling technique consisted of 40 children, 20 students came from early childhood education in Pariaman city and 20 more students were from early childhood education in Padang Panjang City. The instrument used to obtain data in the level of development of the ability of a child Control Object is through the Test of Gross Motor Development-2 (TGMD-2). Based on the results of research conducted, there are differences in the level of ability of Object Control of early childhood education students in Pariaman city and Padang Panjang city with a significant value (Sig) of 0.016 less than the probability of 0.05 . The results of this study indicate that the level of development of the ability of early childhood education students' Control Objects in Padang Panjang City is better compared to early childhood education students in Pariaman city.
\end{abstract}

Keywords—Level of Development, Control Object Ability

\section{INTRODUCTION}

Growth and motor development in young children can be detected in the prenatal period precisely when the fetus is 5 to 6 weeks old in the extension of the upper spine [1]. The basic movement skills possessed by a child at birth will greatly affect the physical activity that will be carried out by children in preschool. The better the basic motion possessed the more active a child will be [2]. Basic movement skills are abilities that must be possessed by children during their growth and development. Basic movement skills encompass coarse and fine movement patterns involving large and small muscles [3]. This basic movement skill is divided into two, namely locomotor abilities (running, hopping and galloping) and the ability of object control (catching, kicking and throwing) as well as jumping and balance [4]. This ability can be obtained and continues to be developed by children at an early age if the child can be incorporated in early childhood formal education such as kindergarten and early childhood education. Therefore, education plays an important role in early growth and development of children [5].

Early childhood education is one form of formal education that is developing in Indonesia. Early childhood education basically includes all the efforts and actions taken by educators and parents in the process of care and education for children by creating an environment where children can explore experiences that provide an opportunity for them to know and understand the learning experiences they gets from the environment, through how to observe, imitate and experiment over and over again and involve all the potential and intelligence of children. In the Republic of Indonesia Education and Culture Regulation Number 84 Article 1 Paragraph (1) of 2014 concerning the Establishment of Early Childhood Education Units [6].

Thus the target of early childhood education according to the law is 0 to 6 years, and can be implemented either through formal, non-formal and / or informal education. Based on the regulation above, it can be seen that early childhood education is the initial stage in the process of children's education to enter further education with a higher level of learning material. The selection of early childhood education as an initial step towards early childhood development is considered to be very appropriate. Many experts say that at the age of 3 to 6 years is a golden period of child development, not only physical and motor development, but also cognitive, psychological and social development of children. The development and growth of children 
can only develop properly if we apply the concept of learning while playing by doing physical activities.

\section{OBJECT CONTROL LEVEL}

The basic movement skills possessed by children are seen to affect many aspects of life. Children who have good basic mobility are able to socialize and participate in many activities in the community during early childhood until adolescence [7]. Basic mobility is considered as the initial foundation in activities throughout life [8] [9] [10] Basic mobility skills are the beginning to improve abilities in various sports (Haubenstricker \& Seefeldt) [11].

Basic motion skills are considered as the basis for competence [12]. The basic mobility ability is divided into two big groups, namely the ability of the control object and locomotor [13]. The locomotor ability is the motion that moves the body from one point to another while the ability of control object is the object manipulation movement.

The ability of the control object is the ability to improve the performance of the muscles in making controlled movements using objects or things. Object control skills consist of (1) throwing (overarm throw) (2) kicking a ball (kicking), (3) kicking a ball that is self-propelled (punting), (4) running with the front legs (leap), (5) hitting the ball with a tool (racket) in a state not moving from above (overarm stricking a stationary ball) [14]. The portion of skills possessed by each child for mastering the ability of this control object is different. This difference in ability is influenced by many factors, including: eye-hand coordination, body mass index, heredity, gender, social environment, parenting style, parental knowledge, and children's confidence.

This object control ability measures the ability to throw, catch, reflect, hit, roll and kick a ball based on the TGMD-2 instrument for children aged 5 to 6 years that was conceived by Ulrich. Every skill displayed by students will be captured on video. The assessment is done by coding the video. Each skill assessed has several characteristics that must be fulfilled by students. Every move made will be assessed at what level the movement is. Movements are performed 2 times each for each skill. In the TGMD-2 test, there are some equipment needed, including plastic hitters, tennis balls, plastic balls with a diameter of 4 inches, plastic ball with sizes of 8 to 10 inches, tennis balls, basketballs, gauges, ball buffer, and upright cones. All research data and equipment are stored in the archive room.

\section{THE DATA ACQUISITION SETUP}

The ability of child control objects is obtained through the Test of Gross Motor Development-2 (TGMD-2) which consists of strike, catch, dribble, kick, throw and roll. Each skill assessed has several characteristics that must be fulfilled by students. Every move made will be assessed at what level the movement is. Movements are performed 2 times each for each skill. In the TGMD-2 test, there are some equipments needed, including plastic hitters, tennis balls, plastic balls with a diameter of 4 inches, plastic balls with sizes of 8 to 10 inches, tennis balls, basketballs, gauges, buffer balls and upright cones. All research data and equipment are stored in the archive room.

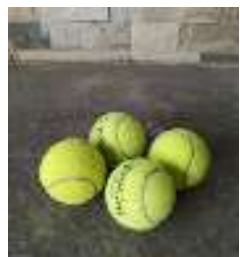

Picture 1. Tennis bal

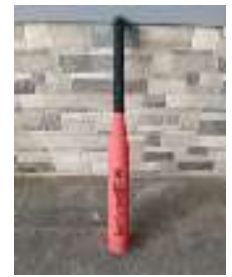

Picture 2. Bat stick

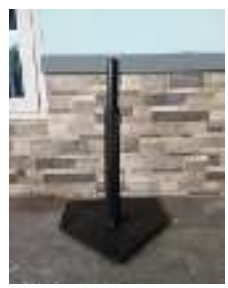

Picture 3. Batting tee

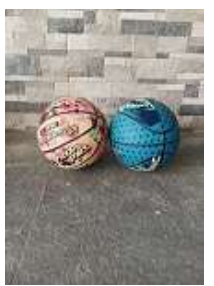

Picture 4. Soft basketball

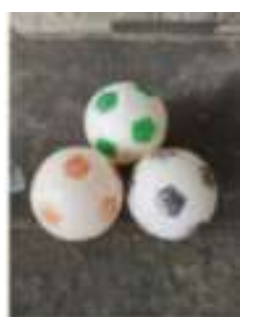

Picture 5. Plastic foot ball

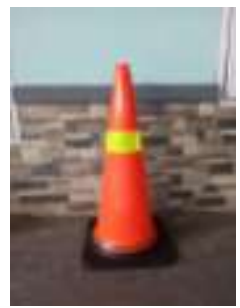

Picture 6. Traffic cone 


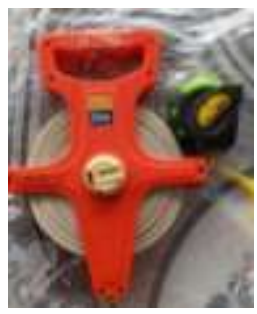

Picture 7. Gauge

\section{THE DATASET}

Data on the level of development of early childhood education students' object control ability in Pariaman City and Padang Panjang City were taken 2 repetitions for all children for each skill tested. Data from the test is stored in video format. The grading of the ability of this object control is based on the TGMD-2 evaluation sheet. Each skill assessed has several characteristics that must be fulfilled by students. Every move made will be assessed at what level the movement is. Movements are performed 2 times each for each skill. In the TGMD-2 test, there are some equipment needed, including plastic hitters, tennis balls, plastic balls with a diameter of 4 inches, plastic balls with sizes of 8 to 10 inches, tennis balls, basketballs, gauges, ball buffer, and upright cones. All research data and equipment are stored in the archive room. This test is given to children aged 5 to 6 years. The number of students involved was 40 people, 20 students from early childhood education in Pariaman city and 20 students from Padang Panjang City.

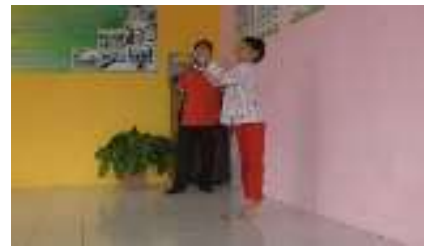

Picture 8. Illustration of chatching the ball

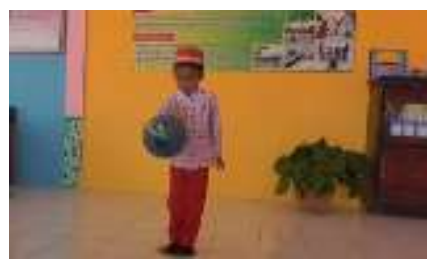

Picture 9. Illustration of reflecting basketball

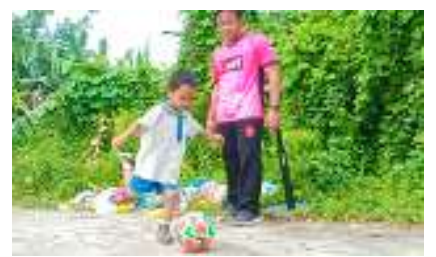

Picture 10. Illustration of kicking the ball

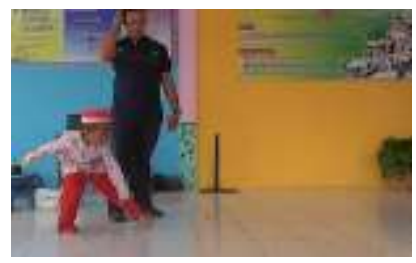

Picture 11. Illustration of rolling the ball

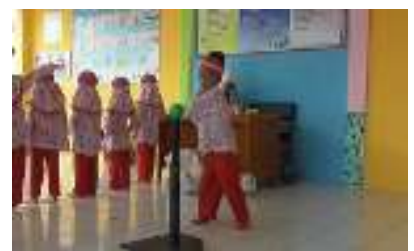

Picture 12. Illustration of hitting the ball

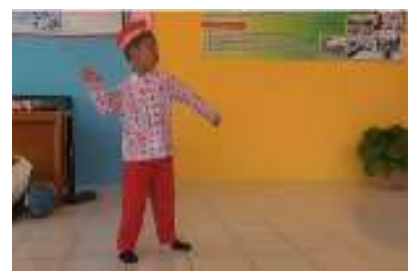

Picture 13. Illustration of trowing the ball

\section{CONCLUSIONS}

The data obtained in this study have a fairly good quality because it used a valid instrument and all the criteria of the control object's skills that are examined have been coded by the experts. The study was conducted on early childhood education students aged 5 to 6 years. it is recommended that parents and teachers can educate and pay attention to the ability of the control objects which the students have. In the future, we will try to apply a learning model that is in line with the early childhood education curriculum in Indonesia. Further research needs to be done related to variables that affect the ability to control object of a child with a wider sample.

\section{REFERENCES}

[1] Malina, R. M. "Physical Activity and Fitness: Pathways from Childhood to Adulthood". American Journal of Human Biology 13, (2001)162-172.

[2] Cliff, DP., Okely, AD., Smith, LM., McKeen, K. 2009. "Relationships between fundamental movement skills and objectively measured physical activity in preschool children" Pediatr Exerc Sci, 21 (2009), pp. 436-449.

[3] JE Clark, JS. Metcalf "The mountain of motor development: a metaphor. JE Clark, JH Humphrey (Eds.), Motor development": research and reviews, Vol. 2, National Association for Sport and Physical Education, Reston, VA (2002), pp. 163-190.

[4] Gallahue, L David \& Ozmund, C. John. "Understanding Motor Development. Infants, Children, Adolecents, Adults. Indiana": Indiana University. 2002.pp.120-133.

[5] Karlstad, Solveig Hägglund., Samuelsson, Ingrid Pramling \& Malmö, Ingegerd Tallberg Broman. 2009. "Early childhood education and learning for sustainable development and citizenship". Paper to be presented at the 17th EECERA Annual Conference Prague, Czech Republic 29 ${ }^{\text {th }}$ August $-1^{\text {st }}$ September (2007) 
[6] Peraturan Menteri Pendidikan Dan Kebudayaan Republik Indonesia Nomor 84 Tahun 2014 Tentang Pendirian Satuan Pendidikan Anak Usia Dini. 2014.pp.20-34.

[7] Walkley, Jeff ., Holland, Bernie V., Treloar, Rose O'Connor, Justen. "Fundamental Motor Skills: A Manual for Classroom Teachers". Melbourne Vic Australia: Victoria. Department of Education. 1996.pp.121-134.

[8] Pelegrini AM, Barela JA. O que o professor deve saber sobre o desenvolvimento motor de seus alunos. In: Micotti MCDO, ed. Alfabetização: assunto para pais e mestres. Rio Claro: Divisa, 1998:69-80.

[9] Clark JE. "On the problem of motor skill development". JOPERD. 2007;78(5):39-45.

[10] Gallahue DL, Donnelly FC. Educação física desenvolvimentista para todas as crianças. São Paulo: Phorte, 2008.pp.60-69.

[11] Barnett, Lisa M., Beurden, Eric Van., Morgan, J. Philip, Brooks, Lyndon O \& Beard, John. "Does Childhood Motor Skill Proficiency Predict Adolescent Fitness?". 2008.pp.121143.

[12] Flier. "Motor coordination problems in children and adolescents with ADHD rated by parents and teachers: effects of age and gender". J Neural Transom. 2010; 115:211-220. 2010 .

[13] B, Syahrial. Merancang Pembelajaran Gerak Dasar Anak. Padang; UNP Press. 2015.pp.12-25.

[14] Ulrich, Dale A. "Test of Gross Motor Development Second Edition: Examiner's Manual”. Austin, Texas. 2000.pp.45-76.

[15] Barnett, Lisa M., Beurden, Eric Van., Morgan, Philip J., Brooks, Lyndon O \& Beard, John R. "Does Childhood Motor Skill Proficiency Predict Adolescent Fitness?”. 01959131/08/4012-2137/0 Medicine \& Science In Sports \& Exercise Copyright 2008 by the American College of Sports Medicine DOI: 10.1249/MSS.0b013e31818160d3. 2008.

[16] Flier. "Motor coordination problems in children and adolescents with ADHD rated by parents and teachers: effects of age and gender". J Neural Transom. 115:211-220. 2010;

[17] B, Syahrial. "Merancang Pembelajaran Gerak Dasar Anak". Padang; UNP Press. 2015.pp.33-56.

[18] Ulrich, Dale A. "Test of Gross Motor Development Second Edition: Examiner's Manual”. Austin, Texas. 2000.pp.66-97. 